\title{
Where are the Romanies? An Absent Presence in Narratives of Britishness ${ }^{1}$
}

Jodie Matthews

University of Huddersfield, Academy for British and Irish Studies

\section{Absract}

The article explores the exclusion or ghettoization of British Romani experience in narratives of historical Britishness, an action that resounds in contemporary politics and identities. It suggests that scholarship might do more to retrieve quotidian and, in particular, shared histories of British Romani culture, integrating those histories into broader narratives about a national past. This scholarly retrieval of everyday Romani life in the past involves reconsidering what might constitute evidence of this experience, and might be open to rewriting established orthodoxies of Romani/Gypsy Studies, with an awareness of the politics of such subversion.

\section{Key words: Romani, Britishness, History, Exclusion}

In The English at Home, Alphonse Esquiros devotes three chapters of the first volume to 'Gypsies'. There is, he claims, no greater spectacle in the life of the human race than the successive appearance and fusion on British territory of the various races that formed the English nation. Still, he says, the Englishman with his 'peculiar traits' is singular and identifiable. This population was fixed, Esquiros asserts, by the time 'an eccentric and nomadic element' arrived in the form of the Gypsies (Esquiros, 1861: vol. 1, 178; 81; 142-3). The view of Britain's Romani population, indeed Roma populations across the globe, as 'eccentric and nomadic' is one that is dangerously persistent. For instance, Katrin Simhandl has traced definitions of such communities used by the European Union, noting that 'in its earliest stages, the discourse was structured by the category of nomadism' (Simhandl, 2006: 103). While nomadism may be or have been a distinctive feature of some communities labelled as 'Roma' or 'Gypsy' or 'Traveller', it is not necessarily a defining, permanent, or exclusive feature. Esquiros's description is, as with many of the same period, patronising in the extreme. He calls Gypsies 'savages, the Mohicans of England'. But! Gypsy life and culture as Esquiros perceives it forms an important part of the story of British life in this text. The same cannot be said of the way narratives of Britishness are told today. This is not to say that the histories of British Romani people and their representation in various media are completely ignored by scholars or arts, heritage and education practitioners from a variety of backgrounds and disciplines, but it is the place of those narratives that is my focus here.

The study of these communities is not in any way new, formally established in Britain by the Gypsy Lore Society in the nineteenth century and now, in a postcolonial academic context, reviewed critically for the forms of knowledge and power relations that this study established and perpetuated. There have been landmark publications in this field in the last decade or so, including Becky Taylor's 
A Minority and the State (2008) and Another Darkness, Another Dawn (2014), Deborah Epstein Nord's Gypsies and the British Imagination (2006) and David Mayall's Gypsy Identities (2004). The work of Gypsy Roma Traveller History Month (no longer in receipt of government funding) and other local initiatives and heritage organisations such as Worcestershire County Museum at Hartlebury Castle, have brought Romani histories to a wider audience. In most mainstream narratives of Britishness written this century, and at the end of the last one, however, Romani people are only there if you already know where to look (for example, as part of particular events or practices), hence my titular insistence on 'absent presence', as opposed to just 'absence'. They are there, because they fought, worshipped, and worked alongside others; they traded and talked with non-Romanies every day. Their presence is not, though, made explicit.

Britishness, like all national identities, is an idea that is fractured, skewed, slippery, contingent, and perpetually in need of supplement and support. Before even pursuing this particular absence from it, I will be making excuses for the Anglo-centric reading of Britishness that appears in this article. These excuses are based on my source texts, ones that generally elide Englishness and Britishness. I take for granted here some of that historical (and ongoing) slippage - a topic for another issue of Identity Papers, perhaps - and will focus primarily on an English interpretation of Britishness, while conceding that this necessarily results in politically problematic exclusions. In terms of the subject-matter of this article, the experience of people known by various names across time and space, but here as Romanies, has differed and continues to differ in England, Scotland, and Wales: I do not wish to imply a monolithic template of 'British Romani' experience that should be reinserted into all our national narratives. ${ }^{2}$ This intranational difference exists for all the same reasons that my experience of Britishness in Huddersfield differs from that of someone in London, Cardiff or the Scottish Highlands, but also because Romani identities are framed by all manner of nationalist discourses relating to history, romance, culture, land, colonialism, and race, all affecting how Romani people are viewed and treated; because of differing local policies and attitudes; and partly because 'Romani', 'Gypsy' or Traveller' are terms that cover a number of more specific identities (e.g. Romanichals, Kale) that do not necessarily map onto national boundaries. Brian Belton explicitly compares the 'undercurrent [of] Gypsy connectivity' in scholarly literature (for instance, when referring to a transnational identity) to 'an attempt to define contemporary Britishness' (Belton, 2005: 10). My interest here is in how attempts at the latter exclude or ghettoize the Romani experience, whether we consider it as connected, dispersed, or atomized. ${ }^{3}$

I want to start to explore why these documented histories are largely absent from mainstream narratives of Britain's past, describing a reflection on my own reading in this field rather than presenting new historical material or in-depth analysis. Romani histories tend to be told in isolation, if at all. As one $\mathrm{PhD}$ study notes, in particular, 'the occasions when the Gypsies were not perceived to be a 
problem do not $[\ldots]$ tend to be written about in history' (Carter, 2002: 13). Romani history as written by those outside the community is often, then, eccentric (in a literal sense) and pathologising. Romani communities have shared work, leisure, and other relationships with non-Romani people in Britain since the sixteenth century, and yet their voices are usually a ringing absence when 'Britishness' in all its plural complexity is described. Two instances which are exceptions to this rule are both live, public events. In 2009, the University of Huddersfield funded and hosted a lecture series titled 'New Perspectives on Britishness'. Politicians, writers, and others were invited to describe their personal and professional reflections on Britishness. The series began with a talk by journalist and now prospective politician, Jake Bowers, who both reinserted Romani experience into the national narrative and highlighted its ongoing exclusion elsewhere. Crucially, this was not a series of talks about 'otherness', but a set of proposals about what it was to be British; if anything, the series as a whole encouraged reflection on what people with a number of different perspectives shared or rejected on their own terms. Similarly, in 2014, a panel discussion at Bradford Literature Festival on the subject of 'The Meaning of Identity in Contemporary Britain' included poet, writer, and current editor of Travellers Times, Damian Le Bas. I mention these events as rarities: in most discussions of 'Britishness', Romani contributors are notable by their absence. My response to this exclusion is not, lest it should be suggested, an instance of identity 'me-tooism' (or 'they too-ism', as I am not Romani); this is a response to my genuine feeling of mounting surprise as I failed to find the Romani lives I knew should populate narratives of Britishness, having read about them in specialist histories. Professor Wendy Webster, University of Huddersfield, is currently an AHRC Leadership Fellow researching diversity in Britain during the second world war in a project called 'Mixing It'; she and I will collaborate on a paper about British Romani experiences of the war as just one intervention in this narrative absence.

What kind of British histories omit Romani experience? Romani experiences are not the only ones excluded from narratives of Britishness, of course, and the politics of one's relationship to a national narrative cannot be properly explained simply through an inclusion/exclusion dichotomy. There are works on 'varieties' of Britishness (non-white Britishness, adopted/immigrant Britishness, for instance) that can actually end up emphasising the exceptionalism of their subject and strengthening already-existing privilege (of, for instance wealth/class, education, sexuality, gender, perceived race, place of birth, health and dis/ability) of normative subjects in historical narratives. This is absolutely not to say that white national narrative privilege can be undermined with a naïve 'we're all British anyway' approach, but a reminder that, as readers, we might be alert to ways in which ostensible discussion of 'Britishness' as an inclusive term can be a coded way of talking about suspicions that certain groups still do not quite fit the bill. 


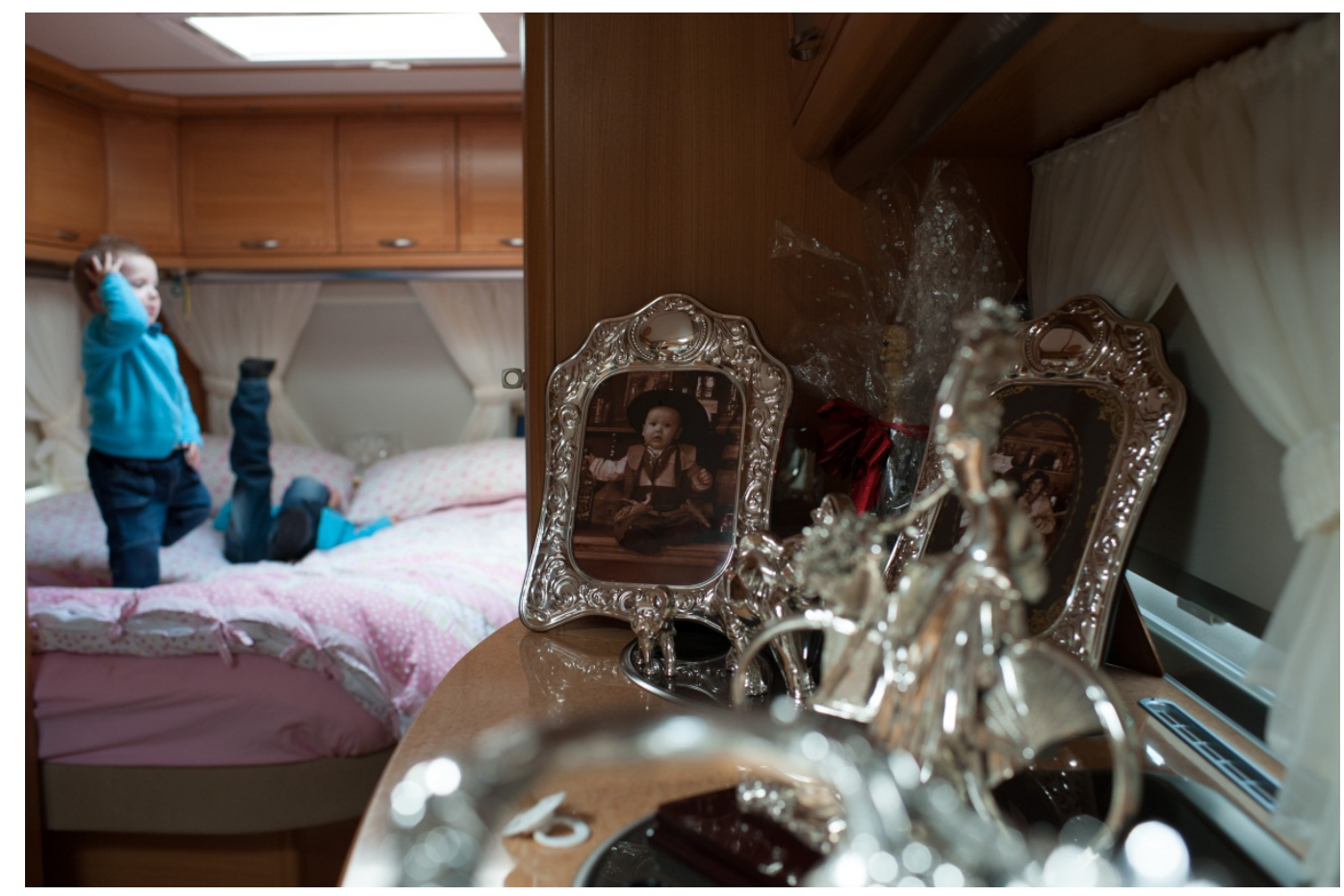

Figure 1: English Gypsy family, the activities of whose ancestors are usually absent from British histories. (C) Ciara Leeming, use only with permission of copyright holder.

The picture of narratives of Britishness I paint is necessarily bibliographically vague, because I am not interested here in labelling other scholars as racist because of Romani absences in their work (though I suggest that, collectively, the omission is racist), or scapegoating just those works I have had the opportunity to read and note the gaps therein - proving an absence is always a problem. Romani figures are textually over-represented to the point of fetishization in imaginative, fictional or creative texts (and not just those that are 'about Romanies/Gypsies'), yet often ignored in mainstream factual, analytical works that have a broad focus on national identity, ethnicity, minorities, diversity, or the history and culture of aspects of British life. Lou Charnon-Deutsch asserts in her work on Europe's obsession with the 'Spanish Gypsy' that: 'to understand Europe's centuries-old investment in the Gypsy as a quintessential other [...] requires a discussion not of sameness but of otherness and othering' (Charnon-Deutsch, 2004: 4). The 'sameness' Deutsch mentions is almost entirely absent from academic study within the Humanities of Romanies in Britain - rarely are the shared histories, overlapping stories and various entanglements of Romanies and non-Romanies part of the narrative - but her assertion certainly reflects the most common approach taken by scholars. For instance, an edited collection analysing the histories and representation of urban and rural spaces points to an often-quoted Romantic description of Gypsies as 'wild outcasts of society'. I have yet to find a broad collection that features Romanies as members of society. They are the perennial eccentrics, a positioning that has farreaching consequences in terms of prejudice. ${ }^{4}$ If Romani people are always portrayed 
as 'outsiders' in cultural representation, the media, and even academia, it can come as no surprise that this pattern is repeated in educational experience, in securing planning permission for a family home, in buying a drink in a pub, or in acquiring employment. Prejudice is rife.

By way of another example, in a study of working-class cultures in Britain, 'Gypsies' score one, negative, mention. Romani experience of seasonal work and the encounters it occasioned are not, for instance, detailed. Various historical 'companions' to periods of British history (the nineteenth century, and the early twentieth century, for instance), and social histories spanning several centuries, may occasionally mention immigrant groups or Jewish communities, yet fail to include mention of Britain's Romanies at all. Primers on oral history leave out this group. Books about what it is and was to travel in Britain neglect the travelling experiences of Romanies, despite that being a major part of the Gypsy stereotype. I have never seen a reference to Romani experience as part of English or British life in a text with 'the nation' or 'the British' in the title. To reiterate, this article reflects on my reading; it is not, of course, exhaustive. It is, I believe, indicative.

Is this just a case of a marginalised group being marginalised by an academic and mainstream discourse, in a way that seems almost common sense given what we know about the pervasiveness of imbalances of power? Every time we write about something, we fail to write about something else. Is this just reluctant yet pragmatic editing because we cannot include everyone? I think it is more complicated than that, especially given the long-standing nature of Britain's Romani population. Public policy interventions (e.g. health, education, planning) focus, for all sorts of pragmatic reasons, on groups that are currently most visible: recent Roma migrants, Romani and Irish Traveller people who travel regularly and/or do not own land, young people whose educational needs are not met. That public policy-led discourse cannot hope to encompass the diversity of Romani identities (e.g. class, dwelling, education), and perhaps contributes, in its homogenising effect, to a collective amnesia about the myriad ways that Romani histories are British histories. I would also argue against any suggestion that the Romani narrative is so well integrated into the multicultural fabric of Britain that it goes unremarked: Romanies are excluded from many aspects of European politics, society, and culture, including in Britain (see, for instance, Agarin, 2014), so to argue that their otherness has been overcome to the extent that scholars and commentators tacitly include them would be disingenuous.

Thomas Acton and Gary Mundy, in introducing their edited collection, Romani Culture and Gypsy Identity, reflected on a collaborative scholarly effort which might 'end the marginalisation of Romani Studies in the world of knowledge', and their aim was to 'challenge the easy assumptions of academic study in and of nationstates' (Acton and Mundy, 1997: 5). Thirteen years later, in 2010, Michael Stewart and Márton Rövid saw that challenge as still unmet, noting 'the difficulty academics have of dealing with a people who are not a people in the sense that nation states 
constitute and make a people' (Stewart and Rövid, 2010: 4). I would add that Romani identity potentially complicates conservative notions of national identity in Britain, meaning that the 'difficulty' Stewart and Rövid describe could help explain Romanies as an absent presence in narratives of Britishness.

More generally, David Mayall notes that 'historians have come rather late to Gypsy studies [even in writing specialist rather than general narratives], and to a large extent the study of Gypsies has usually been undertaken outside the world of mainstream academic history' (Mayall, 2004: 26). Popular, extra-academic works continue to be published in this field but they are most often specialist-interest pieces, rather than ones which weave Romani experience into the national tapestry. While there is certainly enormous value in non-academic oral and cultural histories (among other narrative forms), I do not believe this to be a problem to be solved entirely outside the academy. One solution, I would suggest, is the continued drive towards co-produced research in the Humanities, i.e. research that really does straddle the academic/non-academic boundary in the ways described in Pente and Ward's essay in this edition of Identity Papers; this is research that reflects the constitution of our communities rather than just the interests of overwhelmingly white British research institutions. A drive towards the mainstream in terms of including Romani experience is not, of course, a strategy without intellectual risk; its current absence signifies not just neglect of the Romani past, but other unspoken elements of 'the nation'. A process of reinscribing Romani histories brings with it the possibility of inadvertently reinscribing racist stereotypes that Romani communities and individuals have repeatedly to shake off. These stereotypes are sometimes so culturally ingrained that writers may not realise they are invoking them: an innate urge to travel or for freedom, criminality, wild passions, particular physical characteristics - examples, abound, but see Quarmby (2013: 178-186) for a description of some in action. The risk is mitigated by non-Romani academics considering the effects of their work on people who ascribe to a Romani identity, and working alongside Romani researchers.

Another 'difficulty' those writing narratives of Britishness have struggled with (and it is resolutely their difficulty, not that of the communities about which they write), particularly if they write from within Humanities disciplines, it that academic understanding of the histories and historical representation of Romanies is profoundly shaped by assumptions about what constitutes textual historical evidence, where it might be found, and who has to have written it for it to be 'authentic'. ${ }^{5}$ A clutch of scholarly orthodoxies are ripe for reanalysis because of the way they relate to deeply-rooted ideas about the perceived historylessness of Britain's Romanies. Any scholarly discussion of that perceived historylessness cannot fail to mention Katie Trumpener's essay, 'The Time of the Gypsies: A "People Without History" in the Narratives of the West', which did much to dispel one of the myths about Romani culture in terms of its role and engagement in narratives about our past (Trumpener, 1995). That explicit implication may have gone away, but I fear 
it is implicated in the persistence of claims about archival sources. After the ubiquitous section on definitions (which we academics are prone to get tangled in knots about, sometimes for the right, considerate reasons, sometimes for more sinister ones), many scholarly works proceed to a description of the Romanies' oral culture, and how they left few archival traces behind other than those written about rather than by them. As Deborah Epstein Nord notes: 'although Gypsy voices and stories can be heard in the writings of the [nineteenth-century] Gypsy lorists and other observers, it is difficult to gain access to sustained Gypsy self-representation for much of the nineteenth and into the twentieth century' (Nord, 2006: 167). Nord is correct in saying that the difficulty exists; this auto-archival absence is not as straightforward as it first appears, however.

Paula Toninato explains that 'writing was traditionally only employed by a small elite in interactions with non-Roma', but for much of Britain's history the same could be said of the literacy of the general population (Toninato, 2006: 235). Some of our earliest documentary evidence of the presence of Romanies in Europe in the fifteenth century relates to letters guaranteeing safe conduct; these were written documents whose holders at least understood them - it was dangerous to produce a letter which did not offer what had been verbally promised - and were able to either reproduce them or recognise a decent copy (Fraser, 2003). Thomas Acton notes that the nineteenth century saw 'an increasing professionalization of Romani selfrepresentation in Europe, in the sense that musicians, fortune-tellers and hosts of Gypsy balls and spectacles were able to charge Gaje [non-Romani] for attending their own representations of Romani life' (Acton, 2004: 100). These details mark aspects of the written and/or self-made within the myth of total illiteracy or exogenous representation, particularly if we are open about the definition of writing. I do not assert that Britain's Romani communities did not have primarily oral cultures, and important, distinctive and vibrant ones. Rather, I question the continued use of this predominant orality as a trope or as an exaggerated feature to mark Romani culture as wholly other to the rest of Britain and 'difficult' when it comes to authoritative history writing. This practice runs the risk of reproducing a vision of these cultures as silent (and thus spoken for), separate (and thus marginalised), and subaltern. Deconstructing the opposition between orality and literacy offers a different perspective on the Romani past in Britain, one that emphasises the lines of communication between communities and does not cast the Romani in opposition to a civilised, educated British culture but rather sees him or her as part of British culture.

The opportunity presents itself to rethink what constitutes the documentary evidence we interpret and re-enter the archives with a different approach to retrieving the Romani experience. Anecdotally, a participant at the project workshop undertaken as part of my AHRC research review had investigated local records archives with Romani women researching their family histories. Strikingly, they had told her to 'think like a Gypsy' when looking for sources: individuals had changed 
their surnames for all sorts of reasons, but left archival traces through their occupations and families. Scholars might not, then, find a 'Gypsy archive', but might sensibly look for the Romani traces in all the archives that hold Britain's historical sources. The notion that the historical truth exists only in particular kinds of preserved writing is questioned by Brian Belton, who sees such an archive as 'an empire of writing that exists separately from people like my dad' (Belton, 2010: 43). My assertion that we might rethink archival traces is not to ignore the contribution to archival absence of slavery, genocide and actions amounting to it perpetrated by European states, including Britain, against Romanies and Roma: an element of genocide is the eradication of particular voices in the present and, deliberately, for the future. No-one is left to testify, the stories of those murdered are not accurately told, and others cannot retrospectively find evidence of what happened. For instance, Ian Hancock works tirelessly to ensure the inclusion of Roma and Sinti victims in discussions of the Holocaust, from scholarly works to school textbooks, from which they are currently excluded. He notes, accusingly: 'we are an abstraction, to be discussed in our absence and, worse, even in our presence, as though we don't really exist, with no thought for our feelings or our dignity' (Hancock, 2001: 126). It is my intention to write against such a tendency.

There are four ways in which historians might, and do, defy the genocidal perpetrators of the past that are relevant here. First, we can recognise that there is, contrary to the efforts of perpetrators, always a trace of what happened. It is the scholar's job (be she/he cultural historian, ethnoarchaeologist, linguist or other) to interpret those traces. Second, genocidal actions, in all their devastating effectiveness, were not successful in eradicating all of Britain's Romani voices (through banishment and execution in the sixteenth century) or all of Europe's Roma and Sinti voices (in the Porrajmos or holocaust of the mid-twentieth century). Connecting the lives lost to the family lines that survived is a reminder of that fact. Third, studies of the memorialisation of the execution of Romanies, Roma and Sinti examine the dynamics of memory, shifting depending on context and the discourses in which that memory is articulated. This continued study does justice to the stories we do have and various responses to them. Fourth, and perhaps most rarely, scholarship can draw attention to the fact that Romani and Roma history in Europe amounts to more than systematic victimisation and that there is still considerable work to do to retrieve it. Successful projects of scholarly (and community) retrieval of everyday Romani life in the past that reach beyond living memory necessarily reconsider what might constitute evidence of this experience, are thus necessarily open to rewriting established orthodoxies of Romani/Gypsy Studies, are aware of the politics of such subversion, and do not take for granted an assumption of complete orality. An example of this work is Keith Chandler's article on Romani musicians, which self-consciously mines a wide range of sources as part of a project to understand the lives of people who maintained and transmitted popular pretwentieth-century cultural forms (Chandler, 2011). 
There is, no doubt, a paucity of readily- or obviously-available, catalogued, and tagged archival records produced by Romanies and ready for investigation by the scholar looking for a corpus akin to records of state bureaucracy or of organisations. There are in this field, however, particular archives that might be considered 'privileged': the people who wrote and made the documents and artefacts were in a position to study Romanies, to support each other's work, to publish it or get it published and to make provisions for the survival of that work. Though not all the writers who might fall under this heading were members, for shorthand I refer to the Gypsy Lore Society (Matthews, 2013). Without neglecting to focus on the people the lorists themselves so admired, there is a continued need for scholars to communicate the continuing effects of the lorists' work and the scholarship it spawned. This includes a detailed consideration of the ways in which privileging particular archives maintains both the marginalisation of other histories and other ways of doing history. For instance, Jake Bowers undertook research into the experience of Gypsies and Travellers in relation to museums and heritage services. He found 'both a phenomenal need and a desire within the community to share and preserve its history' but also a 'uniform experience of being ignored by museums, libraries and archives' (Bowers, 2007: 19). The privileging of particular bodies of work and associated scholarly orthodoxies is intriguingly explored by Ken Lee with the notion of a history of amnesia (Lee, 2004).

Very briefly, then, by way of a conclusion, this paper does not call for a convenient way of academically diffusing non-Romani guilt (though many of us might feel it) for the ways in which scholarship has contributed to the daily exclusions of Romani people from British national life. Such a move would merely reflect the interests of the academic and political establishment. Instead, it is a call to deliver on some of the promises made by the changes to study in the Humanities from the 1960s onwards, for instance those heralded under the banner of 'postcolonialism', and continue to ask who orthodox histories exclude, why they do so, and what the effects might be. ${ }^{6}$ 
1. This article draws on an Arts and Humanities Research Council (AHRC) Connected Communities grant for a review of scholarly material in this area, in which some of these issues were explored, and on work that was part of a later AHRC Heritage Legacies project.

2. I have excluded Northern Ireland here because I cannot do justice to the complex relationship and differences between British Romani and Traveller and Roma identities in Ireland in this space. The histories of Irish Travellers in England, Scotland, and Wales are still under-investigated.

3. When quoting directly from texts, I use the epithets in the original, such as Esquiros's 'Gypsies', while noting from the outset that some of this nomenclature is considered offensive today.

4. See, for instance, Rowe and Goodman (2014). Consideration of the use of titles such as theirs as emotional 'triggers' for those who identify as Romani/Gypsy is beyond the scope of this article, but an area for potential future work.

5. 'Authenticity' is a central and problematic issue in commentary about representations of Romani people, and an area I am currently writing about.

6. On the problems and possibilities of postcolonial theory in the twenty-first century see Jackson (2014).

References

Acton, T. and Mundy, G. (1997). Romani culture and Gypsy identity. Hatfield: University of Hertfordshire Press.

Acton, T. (2004). Modernity, culture and 'Gypsies': is there a meta-scientific method for understanding the representation of 'Gypsies'? And do the Dutch really exist? In S. Tebbut and N. Saul (Eds.), The role of the Romanies: images and counter-images of 'Gypsies'/Romanies in European cultures (pp. 98-116). Liverpool: Liverpool University Press.

Agarin, T. (2014). Travelling without moving? Limits of European governance for Romani inclusion. Ethnicities, 14, (6), 737-755. doi: $\underline{10.1177 / 1468796814542184}$

Belton, B. (2005). Gypsy and Traveller ethnicity: the social generation of an ethnic phenomenon. Abingdon: Routledge. 
Belton, B. (2010). Knowing Gypsies. In D. Le Bas and T. Acton (Eds.), All change! Romani Studies through Romani eyes (pp. 39-48). Hatfield: University of Hertfordshire Press.

Bowers, Jake. (2007). Gypsies and Travellers accessing their own past: the Surry Project and aspects of minority representation. In M. Hayes and T. Acton (Eds.). Travellers, Gypsies, Roma: the demonisation of difference (pp. 17-29). Newcastle: Cambridge Scholars.

Carter, H. (2002). Responses to Gypsies in Britain, 1900-1939 (Unpublished PhD thesis). Northumbria University, Newcastle upon Tyne.

Chandler, K. (2011). 'Probably the most widely known gipsy for many a mile around': the life and musical activity of Thomas Boswell, aka Thomas "Gypsy" Lewis (1838-1910). Folk Music Journal, 10 (1), 102-122.

Charnon-Deutsch, L. (2004). The Spanish Gypsy: the history of a European obsession. University Park, PA: Pennsylvania State University Press.

Esquiros, A. (1861). The English at home. (L. Wraxall, Trans.). London: Chapman.

Fraser, R. (2003). Mapping the mind: borders, migration and myth. Wasafiri, 18 (39), 47-54. doi: $\underline{10.1080 / 02690050308589848}$

Hancock, I. (2001). Downplaying the Porrajmos: The Trend to Minimize the Romani Holocaust, A review of Guenter Lewy, The Nazi Persecution of the Gypsies, Oxford University Press, 2000. Journal of Genocide Research, 3 (1), 120-127. doi: 10.1080/14623520120037743

Jackson, S. (2014). Risk, blackness, and postcolonial studies: an introduction. Callaloo, 37 (1), 63-68.

Lee, K. (2004). Belated travelling theory, contemporary wild praxis: a Romani perspective on the practical politics of the open end. In S. Tebbut and N. Saul (Eds.), The role of the Romanies: images and counter-images of 'Gypsies'/Romanies in European cultures (pp. 31-49). Liverpool: Liverpool University Press.

Matthews, J. (2013). 'Tsiganes on the brain: the 'last Gypsy' as a case of archive fever. Immigrants and Minorities, 31 (3), 289-316. doi: 10.1080/02619288.2013.781812

Mayall, D. (2004). Gypsy identities, 1500-2000: from Egipcyans and moon-men to the ethnic Romany. Abdingdon: Routledge.

Nord, D. E. (2006). Gypsies and the British imagination, 1807-1930 (New York: Columbia University Press. 
Quarmby, K. (2013). No place to call home: inside the real lives of Gypsies and Travellers. London: Oneworld.

Rowe, L. and Goodman, S. (2014). 'A stinking filthy race of people inbred with criminality': a discourse analysis of prejudicial talk about Gypsies in discussion forums. Romani Studies, 24(1), 25-42.

Simhandl, K. (2006). 'Western Gypsies and Travellers'-'Eastern Roma': the creation of political objects by the institutions of the European Union. Nations and Nationalism, 12 (1), 97-115. doi: 10.1111/j.1469-8129.2005.00232.x

Stewart, M. and Rövid, M. (Eds.). (2010). Multi-Disciplinary approaches to Romany Studies. Budapest: Central European University.

Taylor, B. (2008). A minority and the state: Travellers in Britain in the twentieth century. Manchester: Manchester University Press.

Taylor, B. (2014). Another darkness, another dawn: a history of Gypsies, Roma and Travellers. London: Reaktion.

Toninato, P. (2006). Translating Gypsies: nomadic writing and the negotiation of Romani identity. The Translator, 12 (2), 233-251.

Trumpener, K. (1995). The time of the Gypsies: a 'people without history' in the narratives of the west. In K. A. Appiah and H. L. Gates Jr. (Eds.), Identities (pp. 338-79). Chicago, IL and London: University of Chicago Press. 